Merima Omeragić

merima.omeragic@unsa.ba

Univerzitet u Sarajevu

Centar za interdisciplinarne studije https://doi.org/10.18485/knjiz.2021.11.11.6

UDK: 172.4:355.106

821.09(497.1-89)-055.2

Originalni naučni članak

\title{
Transnacionalnost u post/jugoslavenskom antiratnom ženskom eseju
}

Rad je utemeljen na ideji zajedničkog reprezentovanoj u esejima post/jugoslavenskih spisateljica i autorki, te odraženoj u angažiranoj: transnacionalnosti, anacionalnosti, antimilitarizmu i feminizmu. Zajednička, transnacionalna tačka esejistkinja Dubravke Ugrešić, Rade Iveković, Jasmine Tešanović, Lepe Mlađenović i Alme Lazarevske razotkriva se u opserviranim i kritiziranim društvenim sistemima nacionalizma koji su uslovljeni patrijarhalnim strukturama. Odnosno, jugoslavenski nacionalni ratni sukobi su, utvrđuju esejistkinje, zasnovani na ratovima među spolovima. Angažiranim pisanjem eseja razgrađen je konglomerat stereotipa (jugoimaginarij) koji potiču od nacionalizovane i militarizovane konstrukcije spola kao i primarne patrijarhalne potrebe kontrole, posebno vidljive u dimenziji kreirane figure majke nacije, te u eskalaciji različitih oblika ratnog nasilja nad ženama. Posebno mjesto u antiratnom ženskom esejističkom diskursu zauzima pozicija spisateljice s (direktnim) iskustvom rata, na primjeru čega je, što je interpretativno istaknuto, moguće najpreciznije se osvrnuti na devastirajući uticaj ratne traume, ali i narativa koji su doveli do upitnosti egzistencije: tradicije, istorije i ideologije nacionalizma. Post/jugoslavenske esejistkinje su zauzimale skoro istovjetne angažirane pozicije otpora, tvoreći uz pomoć alternativnog diskursa sigurne prostore transnacionalnosti. Stoga, korpus post/jugoslavenskog antiratnog ženskog eseja postaje centar novih znanja o našim, i ratovima uopšte.

Ključne reči: antiratni esej, spisateljice, angažman, post/jugoslavenstvo, feminizam

\section{Spisateljice i autorke protiv rata}

Ratnu proizvodnju haosa, užasa, emocija šoka i straha u političkoj dimenziji utemeljuje pooštrena ideologija patrijarhata prožeta projektom nacionalizacije žene. U navedenom procesu Nira Juval Dejvis (Nira Yuval Davis) u Rodu i naciji (1997) detektira križanje roda i nacije ,polazeći od ‘uobičajenih’ uloga žena u biološkoj reprodukciji nacije, preko njihovih uloga u kulturnim tumačenjima nacija do načina na koji civilni oblici nacionalnog, posredstvom prava i dužnosti građana, dobivaju rodni karakter“ (Yuval Davis 2004: 15). Postupak kontroliranja i formiranja poželjne figure žene u ratu determiniran je fenomenom koji Sintija Enlo (Cynthia Enloe) naziva militarizmom ili opravdavanjem i provođenjem akcija u cilju zaštite nacionalne sigurnosti. U knjizi Globalizacija i militarizam (2016) Enlo militarizacijske procese promatra kroz prizmu umanjenja ili obezvrijeđenja brojnih oblika feminiteta, ${ }^{1}$ odnosno marginalizacije žena jer ,one su u ovim izrazito militariziranim i maskuliniziranim regijama danas vidljive tek kao nijeme žrtve ili korisne patriotkinje“ (Enloe 
2020: 47). Odstupanje od modela žene u naciji i ratu (kao i sferi koja definira društveni položaj) označava ulazak na teren borbe za autonomiju koja uključuje: pomjereni rezon, argumentiranje alternativnih spoznaja i artikuliranje glasova žene uprkos moći i dinamici desubjekcije.

Navedene društvene okvire nužno je dekonstruisati i na nivou uloge žene, ali i u polju potencijala konstrukcije antiratnog ženskog teksta. Zadatak čitateljke je da, uprkos marginalizaciji, antiratne narative spisateljica i autorki interpretira kao „neophodan vitalni deo celine“, odnosno iz perspektive koju za oblikovanje feminističkih teorija crnkinja uvodi bel huks (bell hooks), a koja proizlazi iz suprotstavljenog viđenja svijeta koje će nas usmjeravati da „razvijemo ideje i analize koje uključuju različita iskustva“ (hooks 2006: 10). Uprkos monopolu militarističkog narativa, utišani glasovi s margina uzurpiraju prostor bez „dozvole za druge [...] alternativne diskurse“ (Cooper et al. 1989: 19). Promatrani s ovog aspekta, antiratni ženski tekstovi zauzimaju specifičnu poziciju koja se reflektira kroz stvarnost istorijskog događaja raspada Jugoslavije, a iz mikroherstorijskog rakursa - ženskog iskustvenog subjekta utisnutog u tijelo teksta. Unutar literarnog korpusa se ističe žanr eseja za koje Tatjana Rosić u radu „Feministički esej u srpskoj književnosti i raspad Jugoslavije“ (2015) navodi da su „,rezultat angažovanog ‘rukopisa’ spisateljica i teoretičarki s prostora bivše Jugoslavije, koje u svojim tekstovima na kritičko-polemički i analitički način ukazuju na uzroke političke krize, dolazećeg građanskog rata i dezintegracije ne samo SFRJ, već celokupnog nasleđa jugoslovenstva“" (Rosić 2015: 233-254). Angažirane esejistkinje, svjesne ili ne ženske, autorske pozicije, promišljaju ratne užase i komentiraju kompleksnost ženskog položaja u društvu uopšte. Na bazi hibridnosti feminističke autorske poetike i eseja moguće je za istraživačku osnovu istaknuti zajedništvo, a koje u interpretativnim dimenzijama posjeduje jasne konture onog što Tatjana Rosić vidi kao transnacionalni kritičko-esejistički diskurs s feminističkim predznakom.

Polje antiratnog ženskog eseja u post/jugoslavenskom alternativnom i anti/političkom kontekstu obuhvata sklop heterogenih mehanizmama koji redefiniraju angažiranost ispoljenu kroz determinante transnacionalnog: antiratnog, alternativnog, anti/političkog i ženskog. Angažman producira lično [je] političko ${ }^{2}$ opredjeljenje esejistkinja na dekonstrukciju patrijarhalnih i nacionalnih diskursa. Transnacionalnost se definira primarno kao kulturalni proces prevazilaska granica nacionalnih država, te ga je neophodno kontekstualizirati pojmom nacionalizma. $^{3}$

Poslednji segment se ne odnosi na žensko pismo, već na uključivost i pluralnost ženskog zapisanog iskustva, te odlučnost na društvenu promjenu. U jeziku esejistkinja odvija se fuzija intimnog i javnog, koje je ujedno i anti/političko jer podrazumijeva čin podrivanja ideoloških 
svjetonazora na način da se anti/političko etablira kao individualni spisateljski čin protiv nacionalizma i rata kao činova gluposti i zla. Iz direktnog ratnog podražaja na tekst antiratno žensko pismo se etablira u neminovnostima simboličkog, te osim što donosi subjektivne isječke individualnog traumatskog iskustva, forma eseja služi za iskaz egzistencijalnih pitanja vezanih za opstanak žene u ratovima. Otpor ratu raščlanjen do najsitnijeg elementa označava borbu protiv srodne patrijarhalne ideologije i obrnuto, jer „iskorjenjivanje patrijarhata neće izliječiti sve društvene boljke, mora se također iskorijeniti povezani ratni sistem“ (Cooper et al. 1989: 21). Post/jugoslavenski antiratni ženski esej označava alternativni diskurs: pluralnih ženskih glasova s različitih strana novouspostavljenih i zaraćenih granica i (pod)svijesti o ženskom položaju unutar nacionalnih korpusa. Kao takav, esej se pojavljuje kao forma ili hibrid ${ }^{4}$ satkan od autonomnih refleksija na personalna iskustva i poziciju političkog kao anti/političkog.

U interpretativnom fokusu rada nalaze se reprezentativni antiratni ženski eseji zasnovani na razlici pisanja, dakle ideji transnacionalnog i anacionalnog, kao i na humanističkom i etičkom činu pri čemu spisateljski subjekt funkcionira kao autonomna i kulturološka nositeljka teksta/tekstova u kojima se podudaraju premise u jedinstven kognitivni okvir. S ciljem dokazivanja navedenog naučnog konstrukta koristiće se eseji: Dubravke Ugrešić, Rade Iveković, Jasmine Tešanović, Lepe Mlađenović i Alme Lazarevske. Razlog uspostavljanju transnacionalne i anacionalne paradigme je dvostruk. Za razliku od postojećih studija koje se uglavnom odnose na partikularne i jednonacionalne esejističke kanone ili pojedinačna djela ili opuse autorki, primarni zadatak ovog rada je da se napravi iskorak iz takvih ograničenja, da se suoči s potencijalima i izazovima interdisciplinarnih čitanja, te da se kontinuiranim prelaskom utvrđenih barijera izgradi i naučno opiše sintetizirana ideja kod spisateljica i autorki u međudržavnim kontekstima - veza ženskog zajedništva kao referentne tačke (feminističkog) otpora zvaničnim razaračko-ratnim diskursima. Esejistkinje su prevazišle granice i učestvovale u uspostavljanju pluralnog prostora antiratnog otpora. Uporište zajedništvu potiče iz naslijeđa antifašističke borbe, ranijih emancipacijskih praksi i pristupa znanjima koji su oblikovali žene koje pripadaju generacijama autorki antiratnih ženskih eseja.

Kada su u pitanju antiratni eseji, potrebno je sagledati umreženost problema: kulturološke negativizacije ženskog čina pisanja (kanonskog smještanja u bezopasne, rubne žanrove), zahtjev oponašanja poželjnog feminiteta, asimilacije s nacionalnim identitetom i zauzimanja pozicije nacionalnog pisca. U odnosu na lično iskustvo sataniziranja zbog autonomije u pisanju u ključnim godinama rata, Dubravka Ugrešić s pravom dešifrira profil nacionalnog pisca navodeći da je najlakše i najprofitabilnije biti pripadnikom nacionalnog kanona i nacionalnih fantazmi, odnosno biti „književnicom svoga naroda“, ali ipak, „izabrala 
sam neprofitabilniji put: ne želim pripadati nikomu, ni narodu, ni naciji, niti nacionalnoj književnosti“ (Ugrešić 2008: 367). Otpor nacionalnoj, ali i književnoj angažiranosti u kontekstu ratova u kojima se raspala Jugoslavija za spisateljice i intelektualke predstavljao je prišivanje etikete narodne neprijateljice, defektnosti i deformiranosti. Žene u javnom prostoru su prokazane kategorizacijom rada (nastalog na etičkim porivima zaštite umjetnosti i odbrane vrijednosti humanizma) kao izdajničkog, zbog čega su doživjele nasilje i progon, čemu je svakako najzorniji prikaz linča filmske dive Mire Furlan ili slučaj Vještica iz Rija. ${ }^{5}$ Višedecenijski napad na Vještice, koji i danas traje, svjedoči najvišem stepenu tradicionalističkog i instrumentaliziranja žene kojim je zapaljen plamen narodne hajke (iz političkih razloga namjerno ne upotrebljavam riječ histerija, iako se simbolički spaja s inkvizicijskim tehnikama) čiji cilj je: diskreditirati, demonizirati i organizovati lomaču za neposlušne umjetnice i intelektualke. Udar su pretrpjele i žene s drugih nacionalnih strana, koje su se kao Vještice ogrješile o nacionalni koncept žene i odbacile patrijarhalno-nacionalno proskribovan feminitet. Spisateljice i autorke prisutne u javnosti imale su (i imaju) izbor: lojalnosti ka ideološkim vrijednostima nacije, odnosno, prema riječima jedne od vještica, Dubravke Ugrešić, izdaje, svrstavajući se uz jugonostalgiju kojom se definira izdajica koja ne stoji na braniku novokompovane nacionalne domovine, već bira prostranstva lijepe književnosti i „Slobode Govora“ (Ugrešić, 2008: 130). Većina post/jugoslavenskih antiratnih esejistkinja, kao i sama Dubravka Ugrešić, odabrale su put odbrane anacionalnosti, slobode govora i pisanja, te obaveze drugačije i pravičnije participacije u društvenim tokovima. Esejom „Profesija: intelektualac“ iz zbirke Kultura laži: antipolitički eseji (1996), Dubravka Ugrešić je sumirala nasilje i eskomuniciranost kao pesimističnu bespomoćnost, odnosno sumnju u mogućnost i značaj riječi:

Nisam se u znak protesta protiv rata polila benzinom i javno spalila. Nisam obraćala pažnju na postojanu proizvodnju laži, pustila sam da teku niz mene kao prljava voda. Moje su akcije zanemarljive, imale su uglavnom pisanu narav. Pisanom rječju prekasno sam razgnjevila svoju sredinu. Nisam čak, eto, uspjela umrijeti od stida. To što nisu ni drugi ne opravdava me. Da, ja sam kriva! (Ugrešić 2008: 266)

Potresnom autopercepcijom vlastite nedostatnosti pisanja u navedenom citatu razotkriva se skopčanost antiratnog pisanja s težnjom na osmišljavanje egzistencije u ratu. U okviru šokantnog iskaza o samospaljivanju kao konačnom protestu protiv društva rata (smrt kao pečat konačnosti i opomene, ali i završetak postojanja svijeta) i protivteži koja je imanentna pisanju 
- generira se pesimistično iskustvo destabiliziranog identiteta suočenog s mržnjom i opasnosti iz čega se formira ženski subjekt u otporu. Ugrešićkin subjekt pregovara za ugroženo etičko Ja i u borbi, opovrgavajući moć riječi, u čemu bi se mogla u recidivima pronaći i strepnja od autorstva. Naime, radi se o tragu kulturološkog obeshrabrenja spisateljice kroz utjerivanje straha koji usvaja, a što funkcionira kao problem „korjenite strepnje da ne umije da stvara, da će je [...] čin pisanja izolovati i uništiti““ (Gilbert i Gubar 1984: 49) usložnjen napadom na smetajuće devalorizirano tijelo žene koje treba spaliti. Iskazana skepsa u pisanje upućuje na osmišljavanje svrhe pisanja, pogotovo u haosu i bestijalnosti rata i upitnosti egzistencije. U cilju interpretiranja stava Dubravke Ugrešić nužno je posegnuti za dešifriranjem znakova. ${ }^{6}$ Smisao ne može biti determiniran ženskim samo/žrtvovanjem, prije horizont očekivanja treba biti unutar literarno-lucidnog iskazljivog Ja koje se artikulira kao jezički, autonomni, abjektni kulturološki subjekt esejističkih tekstova kao replike povijesti društvenih neprilika. Brutalna autokritika esejistkinje u interpretativnom smislu uslovno može biti istumačena u etičkoj sferi bolne bespomoćnosti da se (ideološko-politički i nacionalno-ratnički) poreci smijene. Ugrešićka ilustrira beskompromisnost pozicije spisateljice što postaje uopšteno mjesto za sve post/jugoslavene antiratne esejistkinje.

Čitateljske strategije pri analizi eseja igraju ključnu ulogu u odbacivanju nacionalne napetosti koja uvjetuje recepciju, to jeste utiče na negiranje alternativnih, ženskih tekstova o ratu. Čitanjem se imanentno traga za vjerom u svrhu tekstova. Naučni pristup integrira poziciju učenja čitanja kao žena, ako se poigramo riječima Anet Kolodni (Annette Kolodny), što determinira generiranje znanja o hipotezi iz domena transnacionalnog zajedništva u post/jugoslavenskom antiratnom ženskom eseju. Ukrštanjem diskursa ženskih iskustava s različitih strana novih državnih granica, a koja su iskazana jezikom, ostvaruje se nova „mogućnost da se čita 'kao žena’“ (Culler 1991: 44), uz nužno osvještavanje da interpretacija služi za izgradnju i učvršćivanje temelja za proizvodnju i kontekstualizaciju drugačijih znanja u sistemima koji pretenduju na cenzuru.

\section{Figura post/jugoslavenske žene: od emancipacije do instrumentalizacije}

Procesu ratne zloupotrebe žene kao majke nacije zasnovanom na simbolu etničkog diskursa koji računa na „gensku zalihu nacije“ (Yuval Davis 2004: 36), doprinosi i fakt da se pripadnost određenom kolektivu određuje rođenjem. Nacionalni nadzor nad prokreativnim sposobnostima ženskog tijela, uz ideje o čistoti rase, ali i krvi, pročišćen je iz pamtećeg karaktera kulturalnih naslaga i neravnopravne distribucije moći između spolova. Aktiviranjem 
stereotipa iz tradicionalnog seta vrijednosti, kreiraju se preporučeni modeli feminiteta metaforizirani nacijom, pri čemu se modeliranje temelji na ulogama žena „kao simboličkih čuvara granica i utjelovljenja kolektiviteta koji ih istodobno kulturno reproduciraju“ (Yuval Davis 2004: 37). Esejistička kritika manipulacije i instrumentalizacije žene kao tijela na kojem se odvija bitka i na koje se kao na mapu upisuju poruke neprijateljima i putem kojih se mijenja strukturna čistoća nacije zasnovana je na početnim pretpostavkama koje se vezuju za deemancipacijske prakse posljednje faze socijalizma, a koja se odvila u nacionalpopulističkom ambijentu 80-ih godina 20. vijeka u Jugoslaviji.

U eseju „(Ne)predstavljivost ženskog u simboličkoj ekonomiji: Žene, nacija i rat nakon 1989 godine“ (2000) Rada Iveković se osvrće na značaj učestvovanja žena u oslobodilačkom pokretu u Drugom svjetskom ratu, što je poslužilo za temelj (primarno kroz aktivnosti Antifašističkog fronta žena) za postizanje vidljivosti kroz reprezentaciju u političkoj i društvenoj sferi. ${ }^{7}$ Posljednje decenije jugoslavenskog društva su obilježene izrazitim deemancipacijskim pokušajima za koje Rada Iveković daje ocjenu privida ako se uzme u obzir da ,vidljivost nije istinski praćena ni podržavana dubokim promjenama u društvu, ponašanju ili uvjerenjima u pogledu žena“ (Iveković 2000: 18). Tokom 80-ih žene su bile „postepeno eliminirane iz javnog života i ono malo posredne političke reprezentacije“ (Iveković 2000: 18). Nada Ler Sofronić u knjizi Neofeminizam i socijalistička alternativa (1986) upućuje na potrebu dijalektičko-istorijske analize položaja žene u socijalizmu u odnosu na oslobođenje od patrijarhalnih okova. Kao centralni problem socijalizma navedeno je formiranje žene u svijetu manipulacije materinstvom, odnosno „kroz polnu socijalizaciju i pristajanje na ulogu drugog“ (Ler Sofronić 1986: 121). Protivrječnosti socijalizma prenijete su i u nacionalne sisteme iz razloga njihovog povratka na „istorijske svesti [koje] se fiksiraju, vulgarizuju i funkcionalizuju u službi autoritarne vlasti, ekstremno represivne socijalizacije, hermetičkog osujećenja kritičke svesti i autonomne prakse, totalne ideološke kontrole“ (Ler Sofronić 1986: 131-132). U nacional-populizmu, slika žene je kreirana uz tradiciju, nacionalizam i mizoginiju. Jasmina Tešanović u eseju „Žene i rat“ iz zbirke Balkan ne postoji (2004) dekonstruiše mehanizme modeliranja žene koji su se odvijali paralelno u svim krajevima Jugoslavije.

Konstrukcija starog-novog modela može da se definiše u tri reči: instrumentalizacija, tradicionalizacija i naturalizacija žena za vreme rata a naročito za vreme nacionalističkih ratova. Zato što je to trenutak kad se društvo totemizuje: svaki nacionalizam pozitivan ili negativan, konstruisan je na različito konstruisanom muško- 
ženskom odnosu ali postoji u svima jedna zajednička tačka: muškost muškarca se forsira kao podređenost žena. (Tešanović 2004: 16)

Preplitanjem procesa instrumentalizacije, tradicionalizacije i naturalizacije generira se poželjna figura žene/nacije otjelovljene njenim biološkim moćima i patrijarhalizovanim feminitetom. S tim procesima dolazi do poimanja žena kao „prirodnih granica“ (Juval-Dejvis 2015: 122) nacije. Istovremeno, evociran je simbolizam domovine ili istorijsko-kulturološki zalog viktimizacije, što je pojačalo instrumentalizaciju žene u nacionalističkim ratovima. Instrumentalizacija se nameće kao problem odnosa među spolovima koji je duboko politički proces. Jasmina Tešanović s razlogom ukazuje na okidač i rezultat distribucije rodne moći jer je i rat prevashodno izražen u tom hijerarhijskom odnosu - forsiranju muškosti muškarca i podređenosti žene. I Rada Iveković u već pomenutom eseju ističe naturalizaciju kao značajnu za održavanje etnokracijskog poretka. Naturalizacija je zasnovana na subordinaciji žene, te stoga taj ideal postaje osnova svim drugim svođenjima: klasnom, rasnom i nacionalnom. Društvena promjena u smjeru individualnog i kolektivnog esencijaliziranja neprijateljskih Drugih u cilju je ostvarenja dominacije nad njima. Zahvat omogućava filozofska asimetrija definiranja jednih uz pomoć Drugih ( $m i$ naspram njih), odnosno vječito negativna kulturološka slika različitih od normiranih nosioca moći.

Ovi se postižu putem historijskog procesa naturalizacije, esencijalizacije podređenog člana jedne dihotomije koja se početno i apstraktno prikazuje kao simetrička. Podređena klasa, rasa, etnička grupa, nacija (sve redom historijski i društveni konstrukti, i dakle relevantne fikcije) se feminizira (naturalizira) da bi se njeno poređenje učinilo prihvatljivim, da bi izgledalo prirodno. (Iveković 2000: 11)

Obrazac o feminizaciji neprijateljskih nacionalnih skupina pitanje je obezvređivanja i podređenog položaja žena. Parafrazirajći Šeri Ortner (Sherry Ortner) moguće je prepoznati univerzalni karakter Sistema povratne sprege, koji ne samo da aspektira fizičke, društvene i psihološke razlike kao bliže prirodi i samim time proporcionalno negativne, već navedeno institucionalizira u svrhu opšte podređenosti i reproduciranja društvenih modela i konstrukata etničke grupe i nacije. ${ }^{8}$

U feminiziranom društvenom ambijentu odvijaju se mikroprocesi ograničavanja i vraćanja žene u privatnu sferu. „Žene su često žrtve načina na koji država definira kulturne potrebe zajednice u pogledu obrazovanja, braka i razvoda i drugih područja“ (Yuval Davis 
2004: 103). „Žene su u kolektivnoj imaginaciji povezane s decom i stoga sa budućnošću kako kolektiva, tako i porodice“ (Juval-Dejvis 2015: 121). Također, razlog shvatanju potiče iz svrhe porodice kao društveno razdrobljavajuće, koja omogućava ženama „partikularističku vrstu preokupacija, nasuprot onima između porodica koji predstavljaju višu, integrativnu, univerzalističku vrstu preokupacija“ (Ortner 2003: 163). Zahvaljujući biološkim vezama žena se obavezuje poslovima rađanja, brige o potomstvu, čuvanju i kuvanju. Jasmina Tešanović korijen tradicionalizaciji nalazi u društvenom sistemu i porodici: majčinstvu, domaćinstvu i zadatku supruge. „Tradicionalizacija društava se pojavljuje kao posledica ovog fenomena: žene koje su vraćene u kuću sada bivaju konstruisane kao male žene koje se bave malim stvarima po ceo dan: savršene žene, majke, domaćice“ (Tešanović 2004: 17). Interpretacija ove zabilješke je složena jer uključuje pozitivnu nacionalnu figuru žene koja, s jedne strane, praktikuje ispunjavanje prirodnih zadataka, dok, s druge, znači njenu savršenost na osnovu identifikacije s kolektivnim. Kako se u analizi navedenog ne bi izostavila uloga supruge, potrebno je interpretirati ideju heteronormativnosti vezanu za poimanje žene kao inkubatora nacije i pripadnosti kolektivitetu koja se određuje nadzorom nad „sklapanjem braka, prokreacijom, te, dakle spolnošću“ (Yuval Davis 2004: 36). Riječima Elizabet Badenter (Élisabeth Badinter), brak je temelj patrijarhalnog društva koji legitimizira vlast muškarca nad ženom pri čemu sistem opstaje pod uslovima „da brak zadrži značenje razmjene žena; drugi, koji je preduslov prvoga, da bude održana asimetrija spolova, odnosno [...] da žene i dalje ostanu vezane za kategoriju predmeta“ (Badenter 1986: 113). Jasmina Tešanović u kontekstu rata demontira činjenicu da žene nikad ne pripadaju sebi, nego društvu kojim upravljaju muškarci, a koje žene podržavaju. Stoga, ženski identitet je iz druge ruke, sekundaran ili polovan. U odnosu na društvenu distribuciju uslovljenu patrijarhatom, žena prihvata model i konstituira se kao korisna patriotkinja.

Dakle takva država kao i javni identitet još uvek postoje i to ne samo u našoj podsvesti i u psihološkim razlikama, već i u našim zakonima. [...] To je kod žena nešto sasvim drugačije: zato što je nacionalni, državni i javni identitet kod žena uvek identitet iz druge ruke: polovni. [...] Njihova veza sa društvom, njihov kredo je potpuno filozofski, legalno i psihološki druge vrste i prirode od muškarčeve. One konstruišu svoj identitet podržavajući svog muškarca. I u tom smislu, nacionalizam je, kao i histerija, reifikovana bolest muškarca kroz telo žene. (Tešanović 2004: 12) 
Pripadnost žene kolektivnim identitetima je prinudna, stečena rođenjem i vjekovnim tlačenjem, te argumentiranjem u polju nacionalizma. Radi se o militarizaciji koja podrazumijeva odricanje žena od ,individualnog rasuđivanja i znatiželje“ (Enloe 2020: 61) u korist muškarca, vlade i rata ili ideologija. Sintija Enlo ističe karakter ženskog prihvatanja bračnog ugovora koji podrazumijeva podržavanje preferiranih doktrina: porodice i militarizovanog braka. Prisilan identitet (Chhachhi, prema Yuval Davis) žene povezan je sa svim razinama kulturalnih značenja. Savršenstvo žene u akcijama uključuje ispunjavanje domestičkih dužnosti čime se potvrđuje involviranost planovima (reprodukciji, konceptima krvi i pripadanja - etničkog porijekla) i odanosti naciji. $^{9}$

Unutar procesa instrumentalitacije žena se pozicionira kao instrument u rukama ratnika. Spolni element je strukturiran tijelom kao esencijalnim simbolom teritorije i granica, što vodi u ideju „nacionalne čistote“. Tragom tih ideja Jasmina Tešanović i Rada Iveković zaključuju da rat postaje povod iza kojeg se nalazi društveni zahtjev stalnog obračuna muškog sa ženskim spolom. Jasmina Tešanović navodi da rat „,nema veze samo sa muškim ratom, već je to jedan trajni muško-ženski rat. To je polno nasilje...“ (Tešanović 2004: 18). Tu pretpostavku iznosi i Margaret Higone (Margaret Higonnet) u knjizi Civil Wars and Sexual Territories (Građanski ratovi i seksualne teritorije, 1994) gdje konstatira da je rat „,metafora za bitku među spolovima“ (Higonnet 1994: 80). Osim što direktno odražavaju političke relacije, rodni odnosi su poželjni i za analizu „kratkotrajnih ali radikalnih smjena u ženskom položaju koje otkrivaju u kojoj mjeri su arbitrarne naše definicije maskulinog i feminilnog“ (Higonnet 1994: 80). Na temelju patrijarhalnih odrednica maskulinog i feminilnog zasnovana je logika vojništva. Suzan Braunmiler (Susan Brownmiller) u studiji Against Our Will: Men, Women, and Rape (Protiv naše volje: muškarci, žene i silovanje, 1975) stavlja akcent na karakter maskulinog u vojskama, pojašnjavajući da muškost vojničkog i moć oružja, duhovna povezanost ratnika, disciplina i naredbe (hijerarhija) potvrđuje muškarcima njihovu superiornost i žensku pasivnost i inferiornost. U prilog tezi ide užasna provala nacionalizma na primjeru ratnog silovanja u bivšoj Jugoslaviji, kao izravne poruke tuđim ženama kao „simbolički najsigurnijem načinu osporavanja neprijatelju čiste loze, dakle, granica i teritorija“ (Iveković 2000: 26). Riječima Braunmilerove, tijelo silovane žene postaje ceremonijalno ratište, a sâm čin ,poruka muškarca muškarcu, živi dokaz pobjede jednog, a neuspjeha i poraza drugog“ (Braunmiler 2013: 9), ali istovremeno i prilika jer ,rat muškarcima pruža savršenu psihološku pozadinu da daju oduška svom preziru prema ženama“ (Braunmiler 2013: 8). Zbog toga, žena postaje subordinirana figura i meta nacije. Dodirnu tačku s premisama Jasmine Tešanović i Rade Iveković imaju i 
stavovi Dubravke Ugrešić iznijeti u eseju „Mi smo dečki““ (u: Kultura laži, 1996) u kojima kao istinske žrtve ratova navodi žene.

Žene su u ratu izgubile domove, djecu, muževe. Žene su u ratu silovali. Najprije jedni muškarci, zatim često i njihovi muževi (,Iz polupane čaše se ne pije“), zatim strani mediji, pa domaći mediji... U ovom trenutku o prognanim i silovanim ženama i njihovoj djeci brinu - druge žene. Ne muškarci. (Ugrešić 2008: 178-179)

Ratni zločin silovanja zasnovan je na brutalnom nasilju usmjerenom ka ženi. Dubravka Ugrešić ukazuje na pogubnost ratnog silovanja koje donosi pluralne traume i nepopravljiv razdor bića, te stigmu radi zločina, odbačenost i repetitivno nasilje. Navođenjem narodne uzrečice se opservira karakter muškog doživljaja silovanja svojih žena kao poniženja. „U ratu, kao i u miru, muževi glavni teret krivnje za taj užasni zločin prebacuju na svoje žene“ (Braunmiler 2013: 9), što im daje opravdanje da sistemski dodatno terorišu i na same žene stavljaju teret krivice za zločin počinjen nad njima. U pozadini reprezentovanih odnosa nalazi se kod po kojem su „patrijarhalne zajednice izmislile brojna lukavstva kako bi muškarac ostao gospodarem ženina trbuha“ (Badenter 1986: 111). I to je u ratovima najvidljivije, „žene u ratu su poštanski sandučići, tijela koja služe za odašiljanje poruka drugim muškarcima, neprijateljima. Pritom neprijateljima koji su još donedavno bili braća“ (Ugrešić 2008: 178-179). Parafrazirajući ogorčenog poznanika (žene kao medij za prenos poruka), esejistkinja pogađa u srž maskuline nacionalne dogme - dekodirajući jezik svojstven muškarcima.

\section{Esejistkinje vs. logika rata i jugoimaginarij}

Post/jugoslavenske autorke poput Rade Iveković, Lepe Mlađenović i Dubravke Ugrešić u esejima argumentovale su stav o, kako ga Ugrešić imenuje, specifičnom jugoimaginariju koji uz dekonstrukciju može poslužiti za iščitavanje logike rata. Osnovu za razumijevanje ratova u bivšoj Jugoslaviji čine vrijednosti koje determiniraju muškocentrični svijet i disbalans u distribuciji moći među spolovima. Utvrdivši da su naši ratovi suštinski bili bratoubilački, Rada Iveković implicira da unutar tog poretka nije bilo žena. Potcrtavši ujedinjenje u počinjenju ratničkih brutalnosti (usmjerenih protiv žena), esejistkinja bratoubilačko analizira u feminističkom smislu - jer u našem jeziku čak i pojam ,nosi polnu podjelu, čak i porodičnu strukturu“ kroz koju se ogleda moć patrijarhalnog militarizma. U jugoslavenskom toposu bratstvo se artikulira procesima uključivanja (sebi istih muškaraca) i isključivanja i uništavanja 
neprijatelja. Bratstvo ojačava nacionalistički konflikt. Dakle, žene su isključene kao primarni neprijatelji jer militarizovani poredak (bratskog) društvenog ugovora je generiran iz patrijarhalnog prava koje muškarci primjenjuju nad ženama. Kerol Pejtmen (Carole Pateman) u Ženskom neredu (1990) identificira društveni ugovor kao „bratski savez koji konstituira građansko društvo kao patrijarhalan ili muški poredak“ (Pateman 1998: 38). Društveni ugovor su sklopila (oblikovala) braća kako bi uveli patrijarhalno pravo bratstva. Cilj društvene akcije muškaraca je primjeniti ugovor „koji legitimira njihovo pravo i omogućuje im da izvlače materijalnu i psihološku korist iz podređenosti žena“"(Pateman 1998: 49). Na istim postulatima na kojima je strukturirano bratstvo, kodiran je i rat. Stoga, Rada Iveković zaključuje: „Bratoubilački rat i jeste paradigma svakog rata“ (Iveković 2000: 24). Sukus ugovora predstavlja komunikacija s društvenim resursima i drugim muškarcima. Iznjedreno bratstvo (u) ratovima utemeljeno je na osjećaju maskuline lojalnosti. To je „osjećaj odanosti svojim dečkima [koji] igra glavnu ulogu u iskustvu muških boraca. Bez obzira na kontekst i razmjere rata, ratni drugovi, ili muška povezanost, gotovo uvijek se naglase kada se govori o tome kako vojnici mogu izdržati nevjerovatne napore što ih donosi rat“ (Yuval Davis 2004: 138). Apsurdno, muškarac se nameće kao jedini zaštitnik koji performira ulogu zaštitnika nacionalne sigurnosti. Na taj način potvrđuje vlastitu superiornost. Prirodni zaštitnik u patrijarhalnom društvu se smatra i idealnim kontrolorom „feminiziranih zaštićenih ne samo zato što su jači nego i (navodno) pametniji“ (Enloe 2020: 65). Legitimirani ideološkom moći, zaštitnici će činiti strašne zločine.

Logiku kulture nasilja u eseju Prljave ulice (1995) demistificira Lepa Mlađenović polazeći od pretpostavke o rodno uvjetovanom nasilju (muškaraca ka ženama i imaginarnom neprijatelju) podižući je na analoški nivo s ratnim nasiljem. Lepa Mlađenović locira transmisiju svakodnevnog rodnog nasilja u ratno nasilje nad ženama. Na binarnom sistemu opozicija generirano je nasilje nad Drugima. „Ako interferencija spolova potiče zebnju naročito kod muškaraca, možemo shvatiti njihovu agresivnost prema ženama i proces spolne segregacije koji se izrođava u konfliktnost“" (Badenter 1986: 142). U vremenu ratne, ideološke neuravnoteženosti provode se strategije nasilja nad počinjenima. U tom smislu, ratno nasilje funkcionira kao bitna vojna strategija uništavanja neprijatelja. Raščlanjen, problem distribucije moći između spolova zasnovane na očuvanju poretka u kojem ,jedan od spolova raspolaže cjelokupnom vlašću - a to može biti samo muški spol, siguran u postojanost svoje fizičke sposobnosti - on će vladati u užasnom strahu da će mu vlast preuzeti ono Drugo i njega samog pretvoriti u ništa“ (Badenter 1986: 143). Nasilje se etablira kao ključni mehanizam uspostave 
kontrole nad drugima/potčinjenima i trajnijeg očuvanja poretka. Analizom društvene kontrole prioritetne skupine žena je objašnjena logika nasilja.

Sličnosti se mogu videti u logici tlačitelja i ratnika koji razliku stanja Drugosti tretiraju sa mržnjom, razaraju je i zloupotrebljavaju. Sličnosti se vide u iskustvima žena koje su zlostavljane zbog svog pola ili zbog svog etniciteta. [...] Logika rata i logika nasilja prema ženama imaju mnoge zajedničke strategije. Kontrola teritorije Drugog pomoću straha i nasilja jedan je od aspekta ove zajedničke logike. (Mlađenović 1995: 5-8)

Primarni aspekt o kojem esejistkinja vodi računa je mapiranje tijela kao mjesta ispisivanja moći. Kontrola kao disciplinirajuća tehnologija Mišela Fukoa, usmjerena je na metode djelovanja moći putem kojih se oblikuje subjektivnost individue. S obzirom na to da je u središtu njegove pažnje protok moći (provedba politike), načini izvršenja moći su konkretni i partikularni. U ratu moć figurira zahvaljujući uspostavi ratne kontrole koja se postiže mučenjem kao nasiljem. ${ }^{10}$ Mučenje kao dio rituala usmjereno je na tijelo, na žudnju da se fizičko postojanje (ratnog ili ženskog) neprijatelja javno obilježi i da članovi oba kolektiva onog u čije ime se provodi kaznena pravda i drugog kažnjeničkog - shvate ko i zašto je žrtva koja se „žigoše sramom - bilo ožiljkom koji ostavlja na telu, bilo prizorom za javnost, jer ionako je svrha mučenja da se iskupi zločin, time se izmiruju računi““ (Fuko 1997: 35). U ime etničkih dugova neprijateljske drugosti - ona/j koja/i posjeduje karakteristike prezrene drugosti biće podvrgnut/a kontroli i kažnjavanju. Cilj javnih nasilnih rituala proističe iz principa osvete zadavanjem boli, izazivanjem straha i respekta spram moćnika. Taj princip skopčan je s idejom krvi i tla koje služe uspostavi dominacije. Rezultat djelovanja ovog principa je mučenje ili smrt. Logike tlačitelja (po spolu) i ratnika (po etnicitetu) postaju identične u efektu. Cilj jeste napad na tijelo kao biološki sklop i kulturološki simbol. Tijelo determinirano biologijom, patrijarhalnom feminilnosti i nacionalnim identitetom postaje sinonim političkog polja moći. Moć se izražava borbom za oblikovanje, kontrolu, dresiranje i slanje poruka preko tijela žene. Također, tijelo je površina za iznuđivanje znakova. ${ }^{11}$ Muškarci u ratovima koriste žensko tijelo za desubjekciju ličnosti, destabilizaciju identiteta i koloniziranje, mučenje i mijenjanje stanja tijela. Ukratko, patrijarhat je sistem discipliniranja žena. Ratnički patrijarhat se služi strategijama slanja poruka neprijateljima putem njihovih žena.

Zar se nismo toliko puta pitale kako čovek u ratu može da siluje ženu koju mrzi? Kako on može da uđe u njeno telo, jer mi smo mislile ako nekoga mrziš, ne možeš ni da ga 
dotakneš. Pogrešile smo. [...] Mnogi su zauvek prihvatili da ne postoje granice ulasku u telo onih koji su manje moćni od njih. Tako bolje naoružana armija ulazi na „neprijateljsku“ teritoriju. Tako muškarac ulazi u ženu i siluje je. (Mlađenović 1995: 5-8)

Napad na žensko tijelo o kojem diskutira Lepa Mlađenović, u navedenom eseju postaje stjecište strateške bitke: napada na neprijateljsku naciju i osvete muškarca nad ženom. U jugoslavenskim, koji su bili i nacionalistički ratovi, korištena je strategija dominacije nad svojinom. Dominacija je zasnovana nad tehnikama i taktikama u kojima je moguće prepoznati splet snažnih veza ili, riječima Mišela Fukoa, model dominacije je uopšte „neprekidna borba“ (Fuko 1997: 29). Pored napada na set nacionalnih vrijednosti reprezentiranih i identificiranih ženom pripadnicom neprijateljskog naroda, žena individualno i duboko intimno ispašta fizičkim postojanjem. Taj čin, kako dokazuju post/jugoslavenske esejistkinje, ali i sama Lepa Mlađenović, povod je iskazivanja spolnog neprijateljstva muškarca ka ženi. Usporedbom ratne i mirnodopske realnosti putem patrijarhalnog normiranja, esejistkinja izvodi zaključak o univerzalnom karakteru rata: rat je civilizacijski projekt ozakonjen državom i pravom uz moć ideologije nacije. Iz civilizacijsko-istorijskih setova pojmova (tradicija i religija) muškarci uče kako ratovati, osvajati teritorije, vršiti nasilje i zločine nad drugima, kako kontrolirati, mučiti i ubijati u dimenzijama javne osvete. Lepa Mlađenović efektno navodi: „Patrijarhat će ratovati zauvek“ (Mlađenović 1995: 5-8). Ovom konstatacijom se razotkriva karakter patrijarhata u dimenziji spolnih politika koje se prenose i na druge oblasti, poput ratova i uopšte na sve društvene relacije.

Neravnopravnost spolova kao karakteristiku ratova u Jugoslaviji kritikuje Dubravka Ugrešić koja prepoznaje kulturu kao mjesto produkcije nasilja. Stoga, jugoimaginarij funkcionira kao set kulturoloških mema. Sa sviješću o štetnom karakteru mema i moći inficiranja stereotipima svih društvenih pora, Dubravka Ugrešić se obrušava na kulturu koja definira subordiniran položaj žene u porodici, društvu, naciji i posredno preko identiteta jugomuškarca (koji se definira u čoporu muškaraca preko ponižene i isključeno-daleke ženskosti, to jeste ,žene u statusu nižeg bića“ kako stoji u eseju Mi smo dečki [Ugrešić 2008: 169]). Posljedica precizne analize je detekcija svrhe rata između spolova koji služi kao paradigma nacionalističkih ratova, a koja se afirmira u svakodnevnim komunikativnim sistemima: jeziku, muzici, filmu, književnosti i posebno u simboličkom kapitalu vojske. 
Rat je samo aktivirao ono što je u muškom imaginariju oduvijek postojalo. Vicevi i zgode na račun vojske (one bivše) ustupili su mjesto ratnom junaštvu, iskušavanju hrabrosti, a priče o nepobjedivosti na polju kreveta, preselile su se na polje fronta. Ratništvo i seks bogato su se isprepleli. [...] Tradicionalističku ratničko-pornografsku retoriku potvrđuju nazivi oružja (često ženska imena), ratne fotografije (ratnika sa puškom, vojnika koji grle topovsku cijev), ratnička subkulutra (stripovi, „literatura“, šale, humor, „ratnička publicistika“). Ratna propaganda češće prikazuje rat kao privlačnu i uzbudljivu mušku avanturu, rjeđe kao svetu, asketsku borbu za domovinu. (Ugrešić 2008: 174)

U navedenom ulomku Dubravka Ugrešić ukazuje na isprepletenost i zavisnost stereotipa o ženama s politikama ratovanja. Jugoimaginarij postaje pitanje kulture rata utemeljene na mizoginiji i seksizmu. U slučaju izbijanja ratova, ta mjesta u kulturi postaju okidači brutalnijeg ratnog nasilja nad ženama. Radi se o militariziranoj kulturi koja je specifično 80-ih godina 20. vijeka u polju filma, muzike, književnosti, kao i viceva i anegdota u kojima su odnjegovani najpoznatiji stereotipi pojačani vulgarizmima na koje apelira esejistkinja. Katarina Luketić u knjizi Balkan: od geografije do fantazije (2013) proziva književnost kao „rasadnik stereotipova i maskiranih političkih naracija, i u njoj upravo imaginacije o nama i Drugima imaju povlaštenu ulogu kao konstitutivni elementi teksta i prevoditelji poruka“ (Luketić 2013: 265). Proširenjem Luketićkinog zaključka uz spoznaju povećanja dinamike društvenosti pri pričanju viceva (uz neizostavan efekt smijeha na iznesene stavove i poente), komentar Dubravke Ugrešić ukazuje na funkcije stereotipa. Relacija po kojoj funkcionira stereotip je dvostrana: drugi pol je reprezent negativne osobine, dok se prvi oblikuje tipskim/pozitivnim uzorcima iz vlastite kulture. Pomenute forme pripovijedanja nude steteotipne istine kao dogmu s ciljem da „ta značenja budu svima razumljiva i naiđu na odobravanje“ (Luketić 2013: 265). U bazi stereotipa ili jugoimaginariju uspostavlja se konekcija bratstva i produkcije nasilja. Centralno mjesto potvrde muškaraca u jugoimaginariju zauzimala je Jugoslovenska narodna armija na čijim popularnim naracijama se kreirao identitet jugomuškarca. Zahvaljujući patrijarhalnoj moći i konstruktu rodova formirana je figura jugomuškarca i jugožene. Poseban fokus je stavljen na, za post/jugoslavenske esejistkinje, zajednički tip ratne propagande, onaj koji identificira rat kao muški projekt, to jeste na rat kao brutalni obračun među spolovima. Potenciranjem rata među spolovima kao zajedničke premise post/jugoslavenskih antiratnih eseja, osim što je istaknut karakter rata, istovremeno je relativizirana i snaga patriotizma i nacionalizma. Esejistkinje su pokazale da su nacionalna i ratnička ideologija stvorene patrijarhalnim 
strukturama. Iako je ideološka moć neosporna, lakoća s kojom muškarci odlaze u rat i demistificirani okidači privlačnosti i avanturizma pokazuju složenost razloga iz kojih muškarci ratuju.

\section{Rat iz prvog lica ili partikularno esejizirano iskustvo iz Sarajeva}

Krajnje brutalno i ogoljeno iskustvo rata, sa samog fronta u mjestu krvavog četverogodišnjeg stradanja - u Sarajevu kao poligonu ratnih okršaja - u esejima Sarajevski pasijans (1994) reprezentovala je Alma Lazarevska. Knjigu otvaraju proročki tekstovi nastali u osvit rata (april 1991) u Bosni i Hercegovini. U njima nizom vještih naznaka prepliću se ideje utemeljene na civilizacijskim, političkim i medijskim kodovima. Realnost pooštrena užasom i neizvjesnošću koja paralizira, radikalno je transformirana. Obrasci bez kojih se pisanje o ratu ispostavlja nemogućim ostaju prisutni i obilježavaju zbirku iz stranice u stranicu, a tokom narednih godina ${ }^{12} \mathrm{i}$ vitalni su dio spisateljičine imaginacije, pisanja, kao i načina re/konstrukcije, te golog preživljavanja ratne realnosti. ${ }^{13}$ Zatočena u ,limitnoj situaciji“ kako posvemašnju ograničenost ratnim dejstvima imenuje Ivana Maček, Alma Lazarevska prkosnu borbu Sarajlija za opstanak i težnju da se uspostavi privid normalnosti, uopšte kulturu ljudskog (ne humanog) postojanja, stavlja u drugačiji, egzistencijalnom upitnošću definiran kontekst. Spisateljica ulaže „kulturalne resurse i inventivnost u cilju da osmisli ratnodopsko postojanje“ (Maček 2009: 34) hronološki zapisujući i ironijski komentirajući vlastito prisustvo događajima u tom poretku. Njeno pisanje je obilježeno novom iskrenošću - svojevrsnim dokumentiranjem užasa. ${ }^{14}$ Uprkos faktu da „haos i paranoja upravljaju danom“ (Maček 2009: 35), esejistkinja gradi smisao oko smrti, nagona za preživljavanjem i probijanja faktora izvan individualne kontrole, koji manipulativno dominiraju ratnim danima. Pred nezaustavljivošću rata, Lazarevska je direktno „suočena sa terorom nasilne smrti i destrukcije“ (Maček 2009: 34). U konfrontaciji s takvim događajima osjeća etičku odgovornost u spisateljskom angažmanu da artikulira vlastitu iskustvenu istinu, kao i spoznaje o svojim sugrađankama/nima.

U tekstovima koji su prethodili ratu, Lazarevska se fokusira na dva komplementarna fenomena: pamćenje i povijest. Razlika individualnog sjećanja i kolektivnog (kulturalnog) pamćenja vezana je za koncepte subjektivnosti i individualnosti doživljavanja - sjećanje, dok je potonje - pamćenje, kolektivno oblikovan fenomen. U eseju Plombiranje memorije (april 1991) preispituju se zakoni iskustvenog i kolektivnog, koje će biti ili je smješteno u istoriju, pri čemu se u središtu interpretacije nalazi put od personalizovanog zapisa do opovrgavanja ideologije kolektiva. Autonomna perspektiva esejistkinje se može dekodirati ličnom životnom 
istorijom, uz „vlastito mesto sa specifičnim opažajnim položajem“ (Asman, 2011: 23). Njena pozicija je određena umrežavanjem i komunikacijom u zajednici, ali i specifičnim inventarom u posjedu društva. Pripadnost grupi (kulturalnim kodovima) i prelazak s ličnog na kolektivno (i pamćenje) postiže se saglasnošću i kako navodi u Dugoj senci prošlosti (2006) Alaida Asman (Aleida Assmann), učešćem u ritualima i ceremonijama, te kapacitetom da se „minuli događaji tumače [...] komuniciraju i praktikuju tako da ostanu sadašnjica“" (Asman, 2011: 269). Prekoračenje navedenih zakonitosti može se prepoznati kao otpor Alme Lazarevske da učestvuje u kolektivnim ritualima, kakvi su dodirivanje, odlaganje i prezerviranje koji vode ka posjedovanju:

Kopanje po margini /neki vole reći - prahu/ povijesti završava se ovih dana publiciranjem slika uredno složenih PVC kesa u kojima su izložene kosti što su decenijama ležale u jamama. ... Agresivna namjena plombiranja u sprezi s politikantskim ciljevima rezultirala je, evo, jezivo banalnom golotinjom, pornografskom obradom tragedije. Hoće li neko na ovaj način posegnuti i za zemnim ostacima žrtava zloglasnih krematorijuma? Hoće li i u tom slučaju instrumenti speleologa biti zamijenjeni usisivačima i detektorima praha, kad baš sve mora rukom da se dotakne i u PVC smjesti, da bi se povijest konačno imala u svojim rukama? (Lazarevska 1994: 15)

Patološka želja za posjedovanjem vlastite (podvučeno: nacionalne) istorije istaknuta je sukladno pravilu očuvanja i prenosa tradicijskog pokretanja sjećanja, te činjenja dostupnim i javnim. To je ključno kad su posrijedi nacionalni narativi iz(s)vođenjem „na prakse zvaničnog sećanja“ (Karge 2014: 245). Kako primjećuje Hajke Karge (Heike Karge) pri analizi socijalnih praksi kulturalnog pamćenja, ${ }^{15}$ pored političkih elita i drugih aktera „koji usvajaju zvanično postavljene okvire za razumevanje prošlosti, o njima do izvesne mere pregovaraju i putem tih procesa usvajanja i pregovaranja menjaju im oblik“ (Karge 2014: 245). Radi se o narativima tradicije i istorije koje su službi nametanja zvaničnog mita o prošlosti ili kako bi to precizirala Alaida Asman, u prozvodnji emocije i naknadnog doživljaja stradanja svojih - pa i sunarodnika. Lična perspektiva Alme Lazarevske ponajbolje je izražena ciničnim komentarom kojim je sintetizirana trauma ratnog stradanja sa viktimizacijskim (i/ili herojskim) diskursom, i na kraju opozita između kapitala počinioca i žrtava. Uprkos kontinuitetu patnje spisateljica svjedoči, što znači ,napet odnos između procedura objektivne rekonstrukcije [koliko sadašnjeg trenutka nasilja, toliko] prošlosti i empatičnog odgovora“(LaCapra 2001: 87). I s druge strane, 
nemogućnost bilo kakve distance, jer ,jezičke funkcije obezbjeđuju mjere svjesne kontrole, kritičke distance i perspektive“ (LaCapra 2001: 90). Iako se doima nemogućim, esejistkinja je posjedovala racionalnu osnovu u ekspresiji ratnog šoka. Rita Felski u knjizi Namjene književnosti (2008) utvrđuje karakter šoka na način da smatra da ,šok postupno gubi svoju emotivnu snagu i moć mijenjanja svijesti““ (Felski 2016: 152). Preciznije, šok čine dezorijentacija (Felski) i gubitak smisla o postojanju i djelovanju (LaCapra) koji utiču ne samo na percepciju, nego i na pisanje. Antiratne ženske eseje, pa partikularno i ove Alme Lazarevske, treba sagledati kroz optiku šoka reprezentovanog u tekstu - drame proživljenih užasa, rata, destruktivnosti, nasilja i mržnje, direktne patnje. Izražena patnja omogućava „posvjedočiti joj izbliza, uvećanoj na entu, katkad do groznih i krvlju poprskanih tančina“ (Felski 2016: 151). To potvrđuje pojam pasije iz naslova esejske zbirke Alme Lazarevske, a koji ima dvostruko značenje: kartaške igre kao sinonima za ratno poigravanje s civilnim stanovništvom, kao i za ratnu traumu kroz proces trpljenja „koje prelazi u patnju, pasivnost u pasiju, u mučenje“ (Asman 2011: 116). Tekstualizirana trauma i šok neminovno su realizirani pod znakom angažiranosti - konstrukcije pripovjedačkog Ja u eseju. Zapravo, postajanje svrhe pisanja „samo planiranjem promjene“ (Sartre 1947: 23) determinirano je bitkom za slobodu, odbranu i čuvanje određenog (personalnog) ideala vrijednosti. U antiratnim esejima angažiranost na pitanju očuvanja života, te pre/vrednovanja mira kao vrhunaravne vrijednosti jesu fundamentalni okidači otpora političkoj i ideološkoj dominaciji. Bunt izražen esejima Alme Lazarevske nije samo pitanje odbijanja učešća u kolektivnim ritualima (relacioniranim $\mathrm{s}$ nacionalnim politikama razora), već i generiranja autonomnog, antipolitičkog i humanističkog stava. Istovremeno, humanizam spisateljice sadrži i kritiku nacionalističkih elita i procesa formiranja povijesnosti. Lazarevska konfrontira individualno, bolno iskustvo kolektivnim mehanizmima pamćenja. Njenu perspektivu određuje autonomija (uprkos cijeni izlaganja progonu od strane vlastitog kolektiva, jer strane se moraju odabrati i zauzeti), te moć prokazivanja štetnosti bilo kojeg nacionalnog, ideološkog opredjeljenja.

Ogolivši ljudski barbarizam, esejistkinja Plombiranjem memorije osim što razotkriva mračnu stranu propagande (medijske i političke), također, upućuje i na kolektivne mehanizme pamćenja metaforiziranih popravkom pokvarenog zuba, tom neizbježnom (privremenom) fazom koja djeluje pogrešnom snagom kojom neminovno otuđuje pojedince od koncepata sjećanog, preživljenog i humanog. U dramatičnoj borbi za prevlast između iskustvenog i konstruisanog, Lazarevska direktno suočava čitateljku sa činjenicom da moć koju proizvodi ideologija daje primat kolektivnim mehanizmima i povijesnosti, nad ostacima ljudskih tijela žrtvovanih ratu. Zvanični kanon pamćenja na priznaje pojedinačne žrtve (ostatke pakirane u 
PVC), on ih instrumentalizira, omasovljuje u diskurse tumačenja rata. Ovim esejom Alma Lazarevska problematizira to razmeđe tragične individualnosti i zvaničnih politika, koje Hajke Karge uopšte kao fenomen dekonstruiše cjeneći zvanični narativ kao oruđe „represije koji se upotrebljava od 'gore'“ (Karge 2014: 246). Leševi koje je proizvela nacionalna politika postaju idealno oruđe za manipulaciju nacionalnim i istorijskim toposom, identitetom i prisilnim procesom identifikacije s kolektivnim. Posjedovanje povijesti esejistkinja dovodi u vezu s ideološkim prioritetima kao uslovima uhodanog sistema plombiranja. Jezički prizor surovog operiranja s mrtvima spisateljica sumira na sljedeći način:

Iz njenog zemnog praha, iz njenih sasušenih kostiju, alhemičari nacionalne povijesti će potom spravljati efikasne plombe. Ko ne zna ili ko loše poznaje tragediju ovdašnjih jama, dobijat će ko terapiju dozu PVC vulgarnosti. Da nije tužan i zastrašujući, prizor bi bio zarazno komičan. Ovako oskrnavljene kosti, nasilno izuzete iz znakovite tišine jama, podsjećaju me da je neko negdje definirao humor kao ono što blamira imanentnost odvajajući je od transcendentalnosti. Nad ovako izloženim kostima bogohulno je recitirati, dapače i pomenuti Goranovu Jamu. (Lazarevska 1994: 15)

Ulog žrtava u stvaranju nacionalne povijesti u takvim okolnostima postaje primarni zadatak države jer se putem memorijskih znakova: simbola mitologije, tradicije, kulture i istorije stvara pamćenje. Identifikacije sa zajednicom i izgradnja zajedništva znače zamjenu intimnog sjećanja kolektivnim. Ili preciznije, kako to vidi Suzan Sontag (Susan Sontag), a prenosi Alaida Asman - kolektivno (pamćenje) može se tumačiti kao ideološko jer se sastoji od „od skladišta sugestivnih slika koje utiču na verovanja, osećanja i mišljenja ljudi i usmeravaju ih. Reč ideologija implicira da se posredstvom uticajnih slika prenose istovremeno opasni i lažni misaoni i vredonosni sistemi koje bezuslovno treba kritikovati i zatirati“ (Asman 2011: 31). Spisateljica dekonstrukcijom procesa Plombiranja memorije tvori opozitni diskurs koji negira i viktimološku i herojsku (nacionalnu) prošlost, obe zasnovane na ljudskom stradanju.

Alma Lazarevska u esejima pokušava naći „balans između priznavanja i ignoriranja okolnosti u kojima postojimo, a koje su prijeteće po život“ (Maček 2009: 35). Esej La morte di Šatropolis (decembar 1992) otvara pitanje svijesti građanki i građana o ratu koji nije shvaćen u totalitetu. Smrt u nazovi-gradu koji je izgubio civilizacijske aspekte urbane sredine odrednice polis u filozofskom smislu i šatro u slengu, upućuju na jezik (koji upotrebljava esejistkinja) u zbirci eseja radeći na opstanku dinamičnog sistema sporazumijevanja obremenjenog ratnim iskustvom traume i preživljavanja. U šatrovačkom kontekstu Sarajevo 
p/ostaje 'ko fol' grad u kojem životne stilove diktira smrtna prijetnja. Iz individualnog doživljaja traume i grada kao klanice, Alma Lazarevska spoznaje, bilježi i upozorava na iščašenje civilizacije. Direktan susret sa realnošću ratnog nasilja, kako smatra Katerina Kolozova, isključuje identitet u odnosu na politički subjekt nametanjem pritiskajućih moći nasilja. Tim procesom se simbolički izokreće poznati (normalni, civilizacijski) univerzum ovaploćen različitim kodovima grada. Urbani prostor Sarajeva ima moć oblikovanja političkog i diskursivnog, a priroda ovih moći jeste restriktivna. U kontekstu ratnog ograničavanja funkcioniranja grada ,traumatizirajuće fizičke restrikcije kretanja u prostoru - umetnuto je ili se samo umeće u 'eteričnu' delikatnu prirodu identiteta i njegove osetljivosti“ (Kolozova 2007). U takvom kontekstu ograničenosti traumom, Lazarevska može jedino da se obrati svojoj zajednici, kao i sebi samoj, ukazujući na pogubnost naivne nesvjesnosti i kratkovidosti pred snagom rata.

Osim iskustva klanice, ovdašnji čovjek danas spoznaje skoro pa nadrealno iskustvo iščašenja iz dostignutog civilizacijskog konteksta. U već degutantnom licitiranju kad je rat u Bosni počeo /Ravno, pod tri vodoravno/ preferiram datiranje koje uvažava pomenuti aspekt. Zar baš mora granata da pukne, da bismo u redovima za benzin kojeg nema, prepoznali rat. Shvatili, ne shvatili Sarajlije se za nastupajuću zimu moraju snaći. Traje bjesomučna potraga za čvrstim gorivom, u gradu u čijim je žilama presahla električna energija. Potraga bi se mogla, utjehe radi, ludistički preformulirati. Tek toliko da bismo puku borbu za opstanak formulirali na civlizacijski zahtjevnijem nivou. Da bismo ostali stanovnici Grada. [...] Šta ste, cijenjene Sarajlije, danas spremne žrtvovati za plamen na kojem nam se zimus valja ugrijati? Kad smo već kod taština, na vatru bi prvo trebalo baciti sve sarajevske mirnodopske umišljaje i zablude, specifičnu sarajevsku taštinu koja je tako kratkovido i uporno odbijala svijest o ratu. (Lazarevska 1994: 73)

Suočavanje civila sa svakodnevnim potrebama (npr. toplina za vrijeme zimskih hladnoća) ${ }^{16} \mathrm{u}$ haosu i sveopštoj devastiranosti, esejistkinja uzdiže na nivo spaljivanja taštine. Preživljavanje time postaje ne samo osujećeno naivnošću, već i samo smanjenje potencijala za borbu za opstanak ovisi o „snalaženju od trenutka do sljedećeg“ (Maček 2009: 35). Također, u eseju Stvar temperamenta Alma Lazarevska pogađa u sujetu - parodiranjem političke vlasti, kao i u individualnoj dimenziji cinizmom preživljavanja, koje u opskurnim okolnostima dosežu vrhunac gluposti i besmisla. 
Stoji neuništivi Sarajlija pored obećanja spomenice i onaj datum na njoj ga opominje da je red da se dotle i preživi, da eventualni samrtnik u ime spomenice mora odložiti čas izlaska Bogu na istinu. A tako mu se žuri, baš kao i onom Sarajliji koji je uspio srediti sve papire za Ameriku te sad odlaže svoj put ka svjetlosti na kraju tunela, odlaže u ime želje da i on dobije spomenicu. Ovo je jedinstvena prilika da svaki čovjek u ovom gradu u vidu spomenice visi na sopstvenom zidu. Ko preživi visit će! (Lazarevska 1994: 140)

Cinizam prožima tekstove u kojima spisateljica pravi otklon od lične pozicije i kritikuje stavove posmatrača bestijalnog rata. Dokidanje života u najbrutalnijem smislu označava postojanje nasilja usmjerenog ,protiv (nečije) 'fizičkosti'““ (Kolozova 2007). Osuđeni na svoje neželjene identitete, suočeni sa i pred istrebljivačkom mašinerijom satanovnici/e Sarajeva ne mogu pobjeći od realnog, nezauzdanog momenta krize traume i straha pred neizvjesnošću rata. U iskazu rat zadobija obrise simboličkog jer se performira u jeziku i diskursu. Katerina Kolozova interpretirajući ratnu traumu, smatra da se realno oprisutnjuje i znakom i preformativom, odnosno neizbježnošću nasilja koje prati diskurs. Proizvodi poput identiteta i diskursa su izvedeni iz Realnog - koje je specifično traumatično. Paradoksalno, Alma Lazarevska ukazuje na sveprisutnost traume koja u vidu prilike za preživljavanje daje samo novu, realnu šansu za smrt.

Sarajevski pasijans se zatvara esejom All that Pasijans u kome se iz autentične autsajderske perspektive potencijalne ratne žrtve i žene, ali i antiratnog angažmana - isprepliću nadrealna trauma i smrt. U kartaškoj igri bespomoćnosti i čekanja na pravu (i krivu) dodjeljenu kartu, tačnije na spontano angažiranje, ili na sigurnosne intervencije i ličnu nemoć obuhvaćeni su snovi o miru i slobodi.

Očekujući da se stvari što prije i povoljno /da bude kao nekad!/ riješe, prvih su mjeseci gotovo zarazno igrali pasijans. Između ostalog igru čekanja! Čekanje vojne intervencije, druge Olimpijade, kenijade, deblokade, riječju - čekanja. [...] U ovom slučaju uvažavamo da knjiga nosi naziv ne samo po igri strpljenja, već po igri osamljenika, samotnjaka... Ovdje je bio po srijedi splet okolnosti u kojima je svaka riječ postala izlišna te se zato izbjegavao razgovor koji uvijek traži rješenja i obećanja. (Lazarevska 1994: 146) 
U igri pasije ili borbe za opstanak sa moći esejističkog iskaza, Alma Lazarevska reprezentira moć rekonstrukcije ženskog (destabiliziranog) identiteta. Poznati zapadnoevropski kulturološki motiv za kojim poseže je figura žene koja odbija nasilje i zauzima etički stav oličen u figuri antičke heroine Kasandre, junakinje Homerove Ilijade. Proričući tragičan kraj Troje proglašena je ludom, zatočenom i odbačenom, onom koja je izrekla istinu kako bi postala „tuđinkom, izgnanom među svojima“ (Antimilitarizam i žene 2009: 47). Posezanjem za modelom kasandrijskog svjedočenja protiv rata, opomene i javnosti Lazarevska identificira bosansku ženu u kompleksnosti antiratnog i humanog stava. Kako u okolnostima rata da djeluje žena? „Bosanska Kasandra, kao svaka Kasandra, plače nad svojim pasijansom“ (Lazarevska 1994: 147). Uprkos pesimizmu - iskazanom plačem nad bespomoćnošću i gubitkom kontrole nad igrom rata koju igraju drugi (nacionalni ideolozi i političke elite u naše ime), nasuprot iznimnoj moći destabilizacije identiteta, esejistkinja zazivajući Kasandrinu mudrost osvještava princip akcije - zasnovan na moći autonomnog i kritičkog govora. Takvim govorom se negira romantizovan povod rata - otmica lijepe Helene, a argumentira sukob između Grčke i Troje, borba u kojoj „muškarci ratuju da bi na vlasti očuvali muški princip življenja“ (Antimilitarizam i žene 2009: 48). U maniru odbijanja muškog ratničkog principa uništavanja, Lazarevska zna da joj u okolnostima egzistencijalne prijetnje preostaje pisanje kao dokumentiranje užasa, pisanje kao svjedočenje iz ugrožene ženske pozicije o postojanju alternativne antiratne politike. Esejskim iskazom u stanju šoka „trauma se jezičkom artikulacijom oslobađa svoje kapsule“ $\mathrm{i}$ postaje „deo svesnog identiteta“ (Asman 2011: 115). Esejističko pisanje problematizira neprivilegiranost i opasnost militarizma u okolnostima gubitka kormila sopstvenog života, te na taj način pisanje radi na očuvanju života (tekst postoji nakon potencijalne smrti). Putem angažmana u osmišljavanju života stvaraju se značenja „u duboko alteriranim situacijama“ (Maček 2009: 34). Esejistika Alme Lazarevske nad užasom reprezentuje, ono što Dominik LaKapra uopšte naziva „empatičnim neraspoloženjem“ (LaCapra 2001: 37-42) kao odgovornošću za traumatsko iskustvo drugih. Empatija ne funkcionira sa identifikacijom, već afektnim odgovorom na nehumanost čovječanstva. Jedan od afektivnih postupaka je i interpretacija. Čitanje eseja iz zbirke Sarajevski pasijans uvlači nas u proces koji autsajderu omogućava odgovornost da sasluša tuđa traumatska i ratna iskustva. Britki i duhoviti eseji Alme Lazarevske s jasnim moralnim stavom, ne samo da donose nove ironijske uvide u civilizacijska dostignuća u prizmi rata, oni predstavljaju vrijedan doprinos herstoriji i stvaranju paradigme ženskih znanja o ratu koja su a priori podvrgnuta cenzuri koju dominantni narativi sprovode nad nepoželjnim i neprihvatljivim alternativnim pričama. 


\section{Završna promišljanja}

Teza ovog rada generirana je na osnovu esejskih materijala spisateljica i autorki iz različitih nacionalnih korpusa. S fokusom na ideološki aspekt nacionalizma i militarizma koji su doveli do ratnog raspada Jugoslavije esejistkinje su tekstualno oblikovale zapažanja nastala iz osvještene perspektive o kulturološkom kontekstu - refleksije društvenih procesa na spolove. $\mathrm{S}$ obzirom da se u dosadašnjim istraživanjima malo vodilo računa o prevazilasku nacionalnih granica i odbijanju dogmi, otvorilo se polje za novi interpretativni pristup utemeljen na razlici: ženskog alternativnog pisanja o ratu, kreiranju novih znanja, kritici patrijarhalnih i nacionalnih sistema vrijednosti i rata kao odnosa među spolovima.

Esejski zapisi Dubravke Ugrešić, Rade Iveković, Jasmine Tešanović, Lepe Mlađenović i Alme Lazarevske koji su poslužili kao paradigmatski uzorak, iskristalizirali su se s potencijalom za rekonstrukciju kulture rata promatranu iz Drugog (neminovno ženskog i feminističkog) ugla. Problematiziranje rata, osim što je iskustveno diferencirano, te stoga donosi značajna znanja sa suprotstavljenih i zaraćenih strana, označava uključivost koja se kreće u rasponu od teorijske do kritičke analize rata. Esejistkinje dekonstruiraju mizogini i seksistički (patrijarhalni) učinak rata, te argumentiraju tezu da su ratovi u Jugoslaviji koncipirani i realizirani kao ratovi među spolovima, ${ }^{17}$ ali i simultano s neizbježnom nacionalističkom ideologijom i na koncu u sferama konkretnog iskustva rata $\mathrm{s}$ fronta. Interpretacija eseja u radu pokazala je da su post/jugoslavenske esejistkinje, uprkos potrganim kontaktima i zvaničnom neprijateljstvu, zauzimale skoro istovjetne antinacionalne i proženske pozicije otpora. Svojim pisanjem one su demontirale opšta i specifična, tradicionalna mjesta i norme s kojima su naše žene suočavane i suočene. U određenim aspektima njihova sa/znanja moguće je proučavati kroz naučno sintetizirano zajedništvo. U usporednim čitanjima ti tekstovi komuniciraju i nadopunjavaju, tvoreći prostor transnacionalnosti, alternative i angažiranosti, te antipolitičnosti kojima se de(kon)struiraju nacionalni i kolektivni narativi.

Posebnu pažnju esejistkinje posvećuju položaju žene u ratu na način da dekodiraju tradiciju ukazujući na opasnost modela i načina instrumentalizacije spolnog i kolektivnog nacionalnog aspekta identiteta. Istovremeno, dokazana je pretpostavka da patrijarhat u kontekstu rata nije samo u službi borbe protiv neprijatelja, već i društvenog discipliniranja neprijateljskih i žena pripadnica vlastite etničke skupine. Antiratni ženski eseji post/jugoslavenskog korpusa su mjesto otpora setovima vrijednosti: militarističkog patrijarhata i nacionalizma usmjerenim na žene. Eseji, kao i antiratna književnost su ,sjajan izvor moći u borbi protiv represije“(Cooper et al. 1989: 13). Na nivou diskursa i rat i rod mijenjaju značenja, 
„što znači da promjena kao kulturalna kodificira značenje drugačije“ (Cooper et al. 1989: 19). Značenje kao konstrukt alternativnog i antipolitičkog, etičkog tipa pisanja reprezentuje ozakonjenje ženske razlike čime se ,proizvode drugačije figuracije orodnjenog značenja rata u modernom i postmodernom pisanju“ (Cooper et al. 1989: 19). Unutar spoznajnog prostora post/jugoslavenskog antiratnog ženskog eseja razotkriva se i svjedoči blago centrirajućeg znanja o istorijskom značenju kako naših, tako i ratova uopšte.

${ }^{1}$ U binarnom društvenom konstruktu feminitet se percipira kroz subordiniranost, nered i inferiornost.
${ }^{2}$ Svako lično žensko iskustvo može biti locirano unutar sistema i hijerarhije moći, to jeste kao dijela
dominantne politike, te se radi navedenog trpljenja opresije u privatnoj sferi nameće kao značajno
političko.
${ }^{3}$ Usp. Encyclopcedia Britannica (2021). Tekst dostupan na veb-stranici Encyclopædie Britannice: https://www.britannica.com/topic/transnationalism (preuzeto: 17. 6. 2021)

${ }^{4}$ Pri interpretaciji feminističkog eseja u srpskoj književnosti Tatjana Rosić precizno određuje karakter „hibridizacije u kojoj se na kraju dvadesetog veka preispitaju disciplinarne i diskurzivne granice, pri čemu književno i teoretsko- filozofsko mišljenje često zamenjuju mesta, preplićući se“ (Rosić 2015: 233-254).

${ }^{5}$ Indikativan pokazatelj položaja žene u otporu u nacionalističkom kontekstu predstavlja i slučaj Vještica iz Rija. Rada Iveković, Dubravka Ugrešić, Slavenka Drakulić, Vesna Kesić i Jelena Lovrić su oštro i krvavo prozvane i odbačene kao trivijalne autorke i nepatriotkinje jugo-oficirskog porijekla, kao neprijateljice hrvatstva, žene koje su slavu stekle na sumnjivim junakinjama, potom kao frustrirane žene koje su izgubile intelektualnu orijentaciju, bez osjećaja za domoljublje, profiterke jugonostalgije i komunizma. Zapravo, radilo se o otvorenom pozivu na linčovanje, protjerivanje i spaljivanje ljevičarki, feministikinja i antimilitaristkinja, komunistkinja u ime njihovog javnog angažmana - radi kojeg su bile izložene govoru mržnje, seksizmu, mizoginiji i senzacionalizmu. U radikalno nacionalističkom okruženju autorke su beskompromisno udarile na temelje novog demokratskog poretka. Vještice iz Rija, kao i uopšte ostale esejistkinje beskompromisno su stale u stranu odbijanja i borbe protiv nacionalističkog modela žene kodiranog jezikom, istorijom, tradicijom i modelom nacionalnog pisca, i s druge strane, krotke žene koja ćuti (a nacionalizirana je simbolima doma/domovine i majčinstva/nacije). Čin etičkog i antipolitičkog angažmana u javnom djelovanju i pisanju prije svega praćen je neprestanom borbom s okruženjem: intelektualnim elitama, institucijama i partikularno $s$ medijima.

${ }^{6}$ Moć riječi leži u njihovom smislu, kombiniranju i tvorbi značenja i prevodu u alfabetski prostor. Prema Mišelu Fukou (Michel Foucault) jezičke znakove treba ,saznati, prema tome [...] interpretirati: krenuti od vidljivog obilježja ka onome što je iskazano u tom obilježju i što bi bez njega ostala nijema riječ, uspavana u mraku stvari“ (Fuko 1971: 99).

${ }^{7}$ O dinamičnijoj emancipaciji žena u našim društvima moguće je govoriti tek sa Drugim svjetskim ratom, kada se osvijestila potreba za doprinosom i učešćem žena. U kritičnim trenucima pokulturavanja rata, patrijarhalni nagonski okvir o položaju (ali ne i o ulozi) žene biva, kako to primjećuje Sintija Enlo, kao karakteristiku svih ratova - gurnut u stranu, kako bi se podnijele dodatne društvene žrtve kojima su predodređene. U formi ravnopravnog uključivanja u borbu protiv fašizma, heroine Drugog svjetskog rata su izašle u prvi plan boreći se za izgradnju novog, te ravnopravnijeg društva, posebno uz brigu o ženskim pravima i vlastitoj osporenosti u dotadašnjim društvima. AFŽ, osim preimenovanja (1953) je preusmjeren dodatno na porodična pitanja, ograničen aspektima rada i sveden na skoro manifestacijski karakter. Bio je to prvi, ali ključni potez države protiv žena, koji je usmjeren na deemancipaciju i koji je dugoročno odredio njihov daljnji položaj i borbu.

${ }^{8}$ Usp. Ortner, Šeri. „Žena spram muškarca kao priroda spram kulture“. U: Antropologija žene, ur. Žarana Papić i Lydia Sklevicky, 146-177. Beograd: Biblioteka XX vek, 2003.

${ }_{9}^{9}$ Devalvirani potencijali žene proističu iz kulturološkog (maskulinocentričnog) nadziranja i kontrole ženske biologije. 
${ }^{10}$ Iako Fuko u Nadziranju i kažnjavanju (1975) istražuje kaznenu moć, moguće je povući paralelu između načina funkcioniranja ove moći sa ratnim kažnjavanjem jer obje posjeduju elemente teatralnosti, montaže, javnosti, iskupa počinjenog i osuđenog zločina žrtve, te želje da se izmire računi i postigne ritualnost.

${ }^{11}$ Primjer takve prakse je prisilna trudnoća kao rezultat organiziranog čina discipliniranja tijela kroz reproduktivnost. Po eugeničkom diskursu obilježena kao inkubator nacije, žena je predodređena za ponižavanje i manipulativnu izmjenu strukture neprijateljske nacionalne grupe.

${ }^{12}$ Esejski zapisi i komentari društveno-političke realnosti u Sarajevskom pasijansu koje iznosi Alma Lazarevska, a koji se prelamaju kroz prizmu njenog života i iskustvo utopljeno u ratu, uključuju period od maja 1990. do septembra 1994. godine.

${ }^{13}$ Pri čemu se sam čin pisanja nameće u askijanskim okvirima - ples za život i opstanak pod granatama.

${ }^{14}$ U tekstu Ratno pismo Alme Lazarevske: nova iskrenost ili dokumentiranje užasa (2013) Azijada Zahirović polazi od tvrdnji Trvtka Kulenovića i Envera Kazaza da književnost o ratu funkcionira kao dokument stvarnosti. Prilikom razumijevanja prosedea Alme Lazarevske, a na primjeru navedene zbirke, kritičarka primjećuje da je Sarajevski pasijans utemeljen na poetici dokumentarizma ratnih strahota, urbicida, masovnih ubistava, logora, nasilja, grobnica, granatiranja, gladi i slično. Literarizacija ratnih događaja postaje pitanje mapiranja užasa sa zadatkom da sâm/a narator/ka „postavlja pitanje i istovremeno dolazi do spoznaje da se historija, možda, ponavlja“ (Zahirović 2013: 63-79). Informacije o događajima i tragovima postojanja ljudi postaju autentične svjedočeći, ali i materijalni dokumenti ratnog užasa i stradanja.

${ }^{15}$ Na Drugi svjetski rat u kontekstu Jugoslavije, što može poslužiti kao indikator.

${ }^{16}$ Poznati topos ratnih sarajevskih zima je grijanje na vlastitim knjigama. I Dubravka Ugrešić u eseju Priča o geleru i knjizi (u: Kultura laži - antipolitički eseji) u paragrafima naslovljenim kao smrt knjige navodi iskustva Sarajlija koji su se grijali na vlastitim kućnim bibliotekama, posebice sabranim djelima: „Kad se takva sabrana djela čvrsto povežu žicom, gore polako, bez žurbe, poput najboljeg ugljena“ (Ugrešić, 2008: 218).

${ }^{17}$ Uz odgovornost muškaraca za politiku i rat. 


\section{Literatura}

Antimilitarizam i žene. Uredila: Staša Zajović. Beograd: Žene u crnom, 2009.

Asman, Alaida. Duga senka prošlosti. Kultura sjećanja i politika povesti. Beograd:

Biblioteka XX vek, 2011.

Badenter, Elizabet. Jedno je drugo. Sarajevo: Svjetlost, 1988.

Braunmiler, Suzan. „Protiv naše volje: muškarci, žene, silovanje“. U: Ratni zločin silovanja, ur. Staša Zajović i Miloš Urošević, 7-14. Beograd: Žene u crnom, 2013.

Cooper, Helen; Munich Adrienne i Squier Susan. „The Con[tra]ception of the War Text“. U: Arms and Woman: War, Gender, and Literary Representation., ur. Helen M. Cooper, Adrienne A. Munich i Susan M. Squier, 9-24. Chapel Hill \& London: The University of North Carolina Press, 1989.

Culler, Johnatan. „Čitati kao žena“. U: O dekonstrukciji: Teorija i kritika poslije strukturalizma, str. 37-56, Zagreb: Globus, 1991.

Encyclopcedia Britannica (2021). Tekst dostupan na web stranici Encyclopædie Britannice: https://www.britannica.com/topic/transnationalism (preuzeto: 17. 6. 2021)

Enloe, Cynthia. Globalizacija i militarizam. Sarajevo: Mreža za izgradnju mira, 2020.

Fuko, Mišel. Nadzirati i kažnjavati: nastanak zatvora. Sremski Karlovci i Novi Sad: Izdavačka knjižarnica Zorana Stojanovića, 1997.

Fuko, Mišel. Riječi i stvari: arheologija humanističkih nauka. Beograd: Nolit, 1971.

Gilbert, Sandra i Susan Gubar. The Madwoman in the Attic. New Haven \& London: Yale University Press, 1984. 
Hanisch, Carol. The Personal Is Political. 2006. Tekst dostupan na veb-stranici: https://webhome.cs.uvic.ca/ mserra/AttachedFiles/PersonalPolitical.pdf $\quad$ (preuzeto: 13.6. 2021)

Nanisch, Carol. „The Personal Is Political“. In: Radical Feminism: A Documentary Reader, ed. Barbara A. Crow, 113-116. New York: NYU Press, 2000.

Higonnet, Margaret R. „Civil Wars and Sexual Territories“. In: Writing after War: American War Fiction from Realism to Postmodernism, ed. John Limon, 80-96. Oxford: Oxford University Press, 1994.

hooks, bell. Od margine ka centru. Beograd: Feministička 94, 2006.

Iveković, Rada. „(Ne)predstavljivost ženskog u simboličkoj ekonomiji: žene, nacija i rat nakon 1989“. U: Žene, slike, izmišljaji, ur. Branka Arsić, 9-31. Beograd: Centar za ženske studije i istraživanja roda, 2000.

Juval-Davis, Nira. Politika pripadanja - intersekcijska sporenja. Novi Sad: Alumnistkinje rodnih studija i Futura publikacije, 2015.

Karge, Haike. Sećanje u kamenu - okamenjeno sećanje? Beograd: Biblioteka XX vek, 2014.

Kolodni, Anet. „Mapa ponovnog čitanja: Rod i interpretacija književnih tekstova“. Genero, br. 1 (2002): 55-68.

Kolozova, Katerina. „Zamišljanje lica „Realnog“: neka razmatranja o ratu i nasilju“. Elektronsko izdanje časopisa Genero, br. 1 (2007): 1-13. Tekst dostupan na web stranici Centra za ženske studije: http://www.zenskestudie.edu.rs/pdf/katerina.pdf (preuzeto: 17. 6. 2021)

Kurspahić, Nermina. Sarajevski ratni pogledi. Sarajevo: OKO, 1996. 
LaCapra, Dominick. Writing History, Writing Trauma. Baltimore i London: Johns Hopkins University Press, 2001.

Lazarevska, Alma. Sarajevski pasijans. Sarajevo: ZID, 1994.

Ler Sofronić, Nada. Neofeminizam i socijalistička alternativa. Beograd: Radnička štampa, 1986.

Luketić, Katarina. Balkan: od geografije do fantazije. Zagreb i Mostar: Algoritam, 2013.

Maček, Ivana. Sarajevo Under Siege: Anthropology in Wartime. Philadelphia: University of Pennsylvania Press, 2009.

Mlađenović, Lepa. „Prljave ulice“. Ženske studije: časopis za feminističku teoriju, br. 2-3 (1995): 5-8.

Omeragić, Merima. „Kao da me nema: militaristička cenzura ženskog roda“. Zeničke sveske-Časopis za društvenu fenomenologiju i kulturnu dijalogiku, br. 21 (2015): 278-296.

Ortner, Šeri. „Žena spram muškarca kao priroda spram kulture“. U: Antropologija žene, ur. Žarana Papić i Lydia Sklevicky, 146-177. Beograd: Biblioteka XX vek, 2003.

Pateman, Carole. Ženski nered: demokracija, feminizam i politička teorija. Zagreb: Ženska infoteka, 1998.

Rosić, Tatjana. „Feministički esej u srpskoj književnosti i raspad Jugoslavije“. Књижевна историја, 47(157) (2015): 233-254.

Sartre, Jean-Paul. What is Literature? New York: Philosophical Library, 1947.

Siksu, Elen. „Smeh meduze“. ARS: Časopis za književnost, kulturu i društvena pitanja, OKF Cetinje, god. 14, br. 5-6 (2010): 18-31. 
Tešanović, Jasmina. Balkan ne postoji. Beograd: Feministička 94, 2004.

Ugrešić, Dubravka. Kultura laži - antipolitički eseji. Beograd: Edicija Reč, 2008.

Yuval Davis, Nira. Rod i nacija. Zagreb: Ženska infoteka, 2004.

Zahirović, Azijada. „Ratno pismo Alme Lazarevske: nova iskrenost ili dokumentiranje užasa“ (Sarajevski pasijans)“. Bosanski jezik, časopis za kulturu bosanskoga književnog jezika, br. 10 (2013): 63-79. 
Merima Omeragić

merima.omeragic@unsa.ba

University of Sarajevo

Centre for Interdisciplinary Studies https://doi.org/10.18485/knjiz.2021.11.11.6

UDC: $172.4: 355.106$

821.09(497.1-89)-055.2

Original scientific article

\section{Transnationality in Post-Yugoslav Anti-War Women's Essays}

The work is based on the idea of the common represented in the essays of post-Yugoslav women writers and authors, and reflected in the socially engaged transnationality, anationality, antimilitarism and feminism. The common, transnational viewpoint of essayists Dubravka Ugrešić, Rada Iveković, Jasmina Tešanović, Lepa Mlađenović and Alma Lazarevska is revealed in the observed and critiqued societal systems of nationalism, which are conditioned by patriarchal structures. In other words, the Yugoslav national armed conflicts were based on the war of the sexes, according to these authors. Their activist essays break down the cluster of stereotypes (Yugoimaginarium) that stems from a nationalised and militarised construction of sexes, as well as a primary patriarchal need for control, especially visible in the figure of the mother-nation and in the escalation of different forms of conflict-related violence against women. A special place in the anti-war women's essayist discourse belongs to those women authors who experienced war (directly), and are in a position that allows for the most precise reflection on the devastating effect of the war trauma but also of the narratives that led to threatened existence: tradition, history, and nationalism. Post-Yugoslav women essayists wrote from nearly identical activist vantage points of resistance, using an alternative discourse to build safe spaces of transnationality. Therefore, the corpus of post-Yugoslav anti-war women's essays became a centre of new discovery about our and other wars.

Keywords: anti-war essay, women authors, social engagement, post-Yugoslav, feminism 